\title{
Peningkatan Pengetahuan Tentang Pentingnya Keselamatan Dan Kesehatan Kerja (K3) Pada Pekerja Proyek Pembangunan Kantor Walikota Kendari
}

\author{
Noviati*, La Ode Muhammad Yasmin, Sitti Marya Ulva, Andi Mauliyana \\ Program Studi Kesehatan Masyarakat Universitas Mandala Waluya
}

\begin{abstract}
ABSTRAK
Proyek pembangunan Kantor Walikota Kendari merupakan kegiatan yang kompleks melibatkan tenaga kerja, alat dan bahan dalam jumlah besar, baik secara sendiri atau bersama-sama sehingga tingkat kecelakaan kerja pada bidang pekerjaan ini lebih besar dibandingkan bidang pekerjaan lain. Terdapat beberapa pekerja proyek yang menyepelekan salah satu hierarki dalam pengendalian kecelakaan dan penyakit akibat kerja, yaitu masih ada yang tidak menggunakan beberapa Alat Pelindung Diri (APD), sehingga dapat diketahui bahwa pengetahuan para pekerja masih kurang terkait keselamatan dan kesehatan kerja. Pengetahuan akan suatu hal cenderung disertai dengan penerapan sikap. Tentunya hal ini berperan penting dalam mengurangi tingkat kecelakaan dan penyakit akibat kerja, sehingga diperlukan suatu program yang dapat mencegah atau mengurangi terjadinya kecelakaan kerja ataupun penyakit akibat kerja. Tujuan diadakan kegiatan pengabdian masyarakat ini adalah untuk menambah pengetahuan dan mengubah perilaku para pekerja tentang kegiatan Keselamatan dan Kesehatan kerja (K3). Hasil yang diperoleh dari kegiatan pengabdian ini adalah para pekerja telah mengetahui pentingnya Keselamatan dan Kesehatan Kerja (K3). Para pekerja juga sangat antusias mengikuti kegiatan ini karena walaupun mereka sedang dalam keadaan bekerja tetapi mereka sama sekali tidak merasa terganggu dengan kegiatan kami. Para pekerja meluangkan waktu kurang lebih 10 menit karena sosialisasi ini dilakukan face to face. Diharapkan kepada pekerja untuk tetap menaati peraturan terkait keselamatan dan kesehatan dalam bekerja, sehingga dapat tercipta suasana yang aman dalam bekerja. Dan juga kepada pimpinan terkhusus pengawas keselamatan dan kesehatan kerja (K3), jika sudah menerapkan peraturan-peraturan terkait K3, maka perlu dipadukan dengan sanksi bagi yang melanggar.

Kata kunci: Pengetahuan; Keselamatan dan Kesehatan Kerja; Pekerja Proyek
\end{abstract}

\section{Increasing Knowledge About the Importance of Occupational Safety and Health (K3) on Development Project Workers, Kendari Mayor's Office}

\begin{abstract}
The construction project for the Kendari Mayor's Office is also a complex activity involving large amounts of manpower, tools, and materials, either alone or together, so that the rate of work accidents in this field of work is greater than in other fields of work. There are still project workers who underestimate one of the hierarchies in controlling occupational accidents and diseases, namely that there are still those who do not use some personal protective equipment (PPE), so it can be seen that the knowledge of workers is still lacking regarding occupational safety and health. Knowledge of a thing tends to be accompanied by the application of attitudes. Of course, this plays an important role in reducing the rate of accidents and occupational diseases, so we need a program that can prevent or reduce the occurrence of work accidents or occupational diseases. The purpose of this community service activity is to increase knowledge and change the behavior of workers regarding occupational safety and health (K3) activities. The results obtained from this service activity show that the workers already know the importance of occupational safety and health (K3). The workers were also very enthusiastic about participating in this activity because, even though they were at work, they were not at all disturbed by our activities. The workers took approximately 10 minutes because this socialization was carried out face-to-face. It is expected that workers will continue to comply with regulations related to safety and health at work, so that a safe atmosphere can be created at work. And also to the leadership, especially the occupational safety and health (K3) supervisor, if you have implemented regulations related to K3, it needs to be combined with sanctions for those who violate it.
\end{abstract}

Keywords: Occupational Health and Safety Knowledge; Project Worker

Penulis Korespondensi :

Noviati

Universitas Mandala Waluya

E-mail : noviati.novy@gmail.com

No. Hp : 085255085235 


\section{PENDAHULUAN}

Tingkat kecelakaan kerja dan berbagai ancaman keselamatan dan kesehatan kerja (K3) di Indonesia masih cukup tinggi. Berdasarkan laporan International Labor Organization (ILO), setiap hari terjadi 6.000 kasus kecelakaan kerja yang mengakibatkan korban fatal. Sementara di Indonesia setiap 100 ribu tenaga kerja terdapat 20 korban yang fatal akibat kecelakaan kerja. Menurut Menteri Ketenagakerjaan jumlah kasus kecelakaan kerja mengalami peningkatan, yaitu pada tahun 2019 jumlahnya mencapai 114.000 kasus kecelakaan naik di tahun 2020 menjadi 117.000 kasus kecelakaan, dan angka kasus kecelakaan yang sama diperoleh dari BPJS Ketenagakerjaan. Jika angka tersebut dihitung berdasarkan jumlah klaim yang diajukan oleh pekerja yang mengalami kecelakaan kerja, artinya angka kecelakaan kerja yang sesungguhnya jauh lebih besar, karena belum semua tenaga kerja menjadi peserta BPJS Ketenagakerjaan. Sehingga, berdasarkan data tersebut semua dituntut untuk lebih serius dalam menerapkan budaya K3 (Sumardiyono, 2010). Bahkan sejak tahun 2020 pemerintah telah melaksanakan berbagai upaya untuk meningkatkan pelaksanaan K3 secara nasional, antara lain menyempurnakan peraturan perundang-undangan, serta standar di bidang K3 termasuk menyesuaikan, kemudian meningkatkan peran pengawas bidang K3 dalam melakukan pembinaan pemeriksaan, penegakan hukum di bidang $\mathrm{K} 3$, meningkatkan kesadaran dan peran pengusaha tenaga kerja dan masyarakat (Santia, 2021).

Pada hakikatnya keselamatan dan kesehatan kerja merupakan prioritas utama dalam kehidupan manusia. Permasalahan K3 di Indonesia masih dianggap rendah, ini terbukti dari masih banyaknya kecelakaan kerja yang terjadi terutama di sektor konstruksi, inilah yang mengakibatkan banyak terjadinya kecelakaan kerja baik yang serius maupun yang tidak serius bahkan kematian (Ramli, 2010).

Secara umum industri konstruksi adalah industri yang menduduki tempat tertinggi ditinjau dari tingkat terjadinya kecelakaan kerja, Dipohusodo, (1996). H. W. Heinrich dalam bukunya The Accident Prevention mengungkapkan bahwa $\quad 80 \% \quad$ kecelakaan kerja disebabkan oleh perbuatan yang tidak aman (unsafe action) dan 20\% disebabkan oleh kondisi yang tidak aman (unsafe condition). Pada proyek pembangunan Kantor Walikota Kendari juga merupakan kegiatan yang kompleks melibatkan tenaga kerja, alat, dan bahan dalam jumlah besar, baik secara sendiri atau bersama-sama sehingga tingkat kecelakaan kerja pada bidang pekerjaan ini lebih besar dibandingkan bidang pekerjaan lain (Tarwaka, 2008). Berdasarkan survey awal, masih ada para pekerja proyek yang menyepelekan salah satu hierarki dalam pengendalian kecelakaan dan penyakit akibat kerja, yaitu masih ada yang tidak menggunakan beberapa Alat Pelindung Diri (APD), sehingga dapat diketahui bahwa pengetahuan para pekerja masih kurang terkait keselamatan dan kesehatan kerja. Pengetahuan akan suatu hal cenderung disertai dengan penerapan sikap. Tentunya hal ini berperan penting dalam mengurangi tingkat kecelakaan dan penyakit akibat kerja, sehingga 
diperlukan suatu program yang dapat mencegah atau mengurangi terjadinya kecelakaan kerja ataupun penyakit akibat kerja.

\section{METODE}

Kegiatan ini dilakukan dengan cara memberikan penyuluhan kepada para pekerja untuk meningkatkan pengetahuan dan mengubah perilaku mereka tentang kegiatan Keselamatan dan Kesehatan Kerja (K3). Penyuluhan diberikan secara face to face dengan membagikan leaflet terkait K3 (Budiman, 2011).

\section{HASIL DAN PEMBAHASAN}

Kegiatan ini dilakukan pada hari Jumat tanggal 20 Agustus 2021 bertempat pembangunan kantor Walikota Kendari yang diikuti oleh 15 pekerja. Sehubungan dengan kondisi masa pandemi Covid-19, maka kami tidak dapat mengumpulkan pekerja sehingga sosialisasi dilakukan secara face to face kepada para pekerja. Sebelum dilakukan penjelasan terlebih dahulu kami membagikan leaflet kepada pekerja yang ditemui, karena proses kegiatan kami lakukan pada saat pekerja sedang bekerja maka kami hanya mempunyai waktu kurang lebih 10 menit per orang untuk melakukan sosialisasi yang diselingi tanya jawab dari pekerja, seperti terlihat pada gambar berikut:

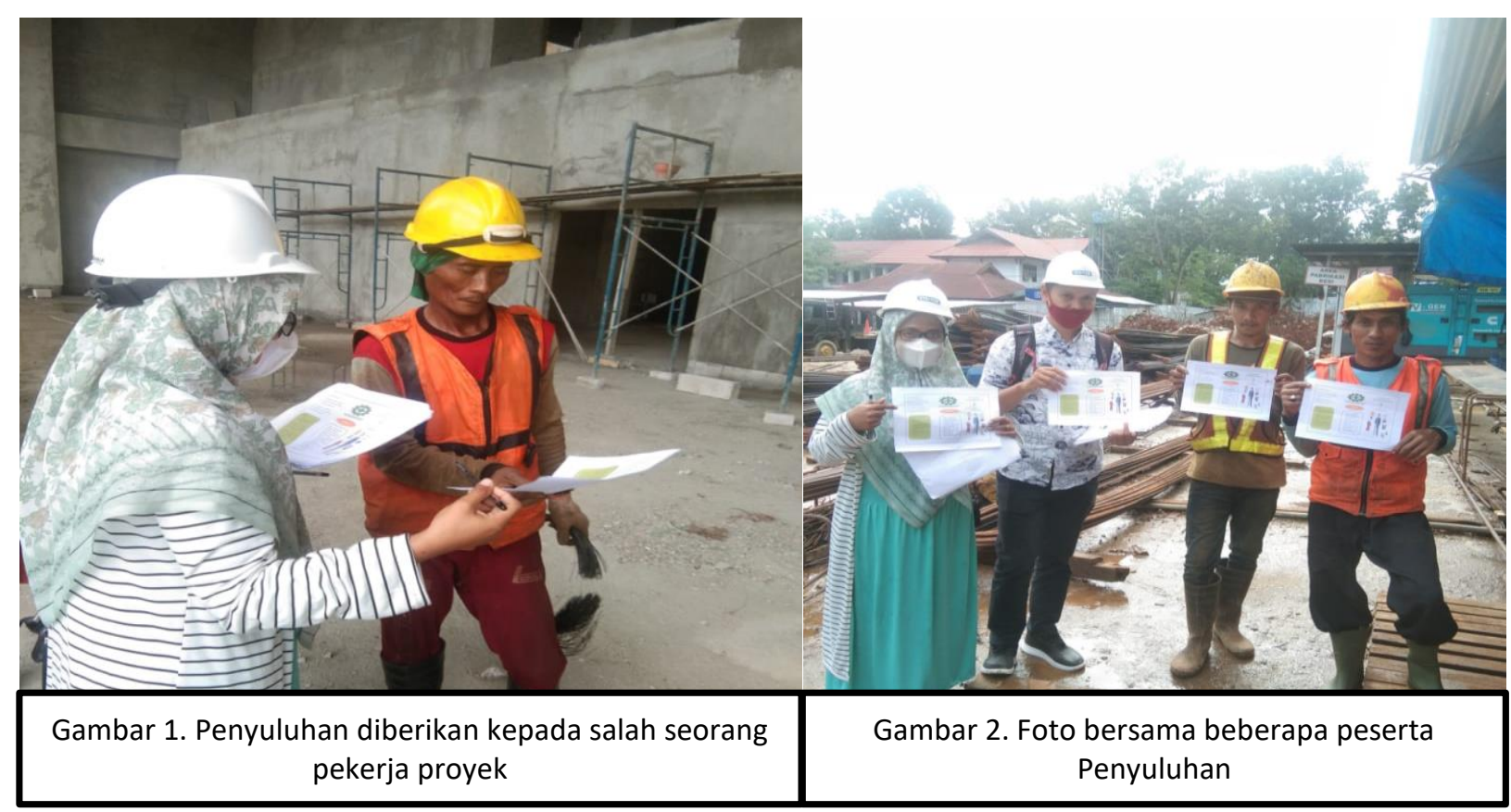


Walaupun kegiatan dilakukan disaat pekerja lagi sibuk bekerja tetapi mereka tetap antusias dalam mengikuti kegiatan ini dan kegiatan berjalan lancar.

Masih ada pekerja yang mengatakan bahwa walaupun mereka tidak menggunakan APD berupa masker dan sepatu kerja (safety shoes) tapi mereka masih selamat dan masih sehat. Hal ini dapat diketahui bahwa pengetahuan pekerja masih kurang sehingga membuat mereka mengabaikan arti penting dari keselamatan dan kesehatan dalam bekerja. Pengetahuan atau kognitif merupakan domain yang sangat penting untuk terbentuknya suatu tindakan seseorang (over behaviour). Karena perilaku yang didasari oleh pengetahuan akan lebih langgeng dari pada perilaku yang tidak didasari oleh pengetahuan. Pengetahuan tentang manfaat sesuatu hal, akan mempunyai sikap yang positif terhadap hal tersebut.

Namun setelah melalui kegiatan kami berupa sosialisasi singkat dan pembagian leaflet terkait pentingnya Keselamatan dan Kesehatan Kerja bagi pekerja proyek, maka mereka lebih memahami tentang risiko-risiko yang dapat membahayakan keselamatan dan kesehatan kerja serta bagaimana pencegahannya. Berikut adalah leaflet yang digunakan saat kegiatan Pengabdian kepada Masyarakat :

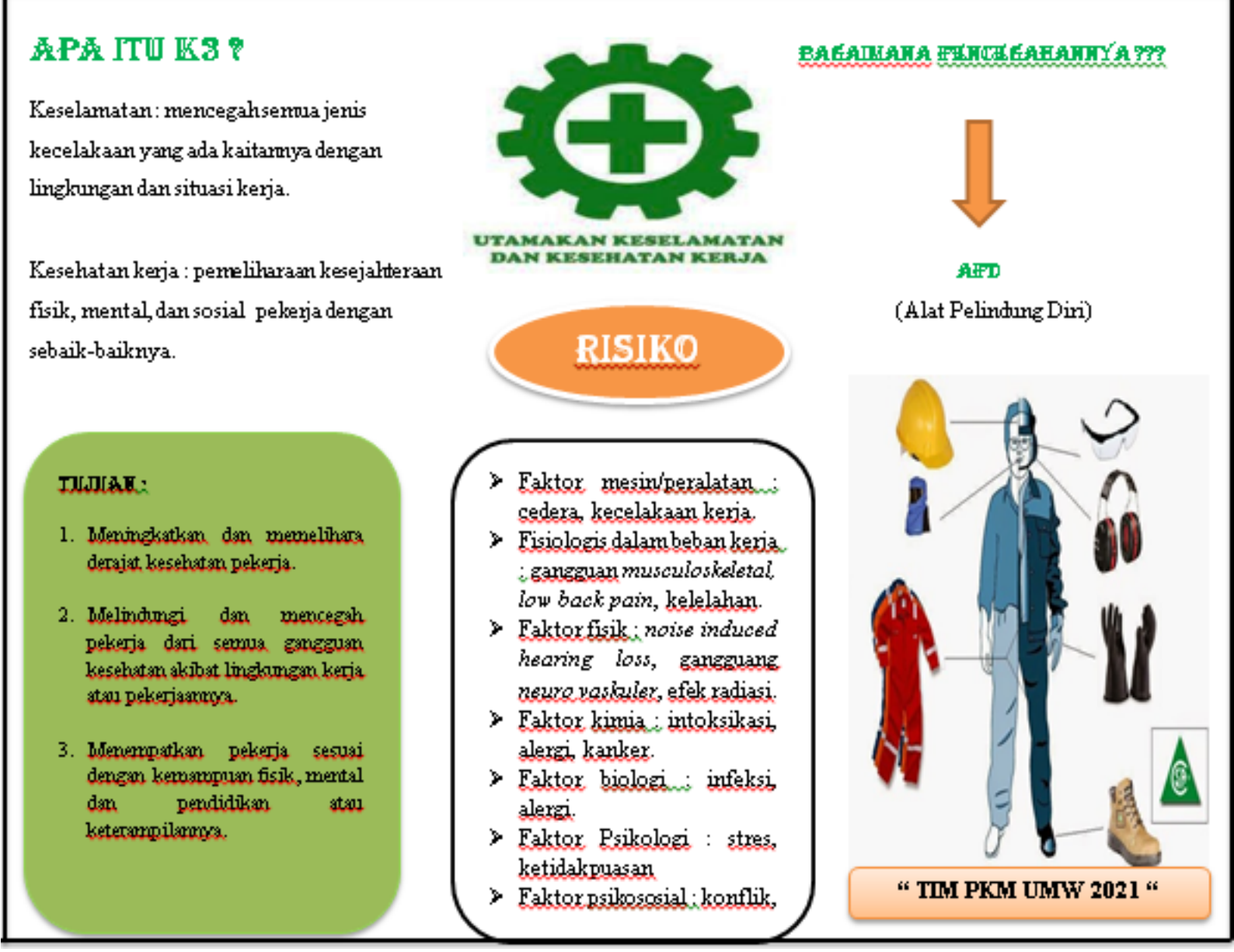




\section{KESIMPULAN}

Berdasarkan hasil dan pembahasan yang diperoleh, maka dapat disimpulkan bahwa :

Para Pekerja telah memperoleh pemahaman dan kesadaran tentang pentingnya keselamatan dan kesehatan dalam bekerja, sehingga meningkatkan pengetahuan mereka dan membuat pekerja lebih berperilaku aman dalam bekerja.

\section{UCAPAN TERIMA KASIH}

Dalam menyelesaikan kegiatan pengabdian masyarakat ini, kami telah dibantu dari berbagai pihak, untuk itu kami mengucapkan terima kasih kepada

1. Ketua Badan Pengurus Yayasan dan Rektor Universitas Mandala Waluya, yang telah memberikan bantuan dana untuk pelaksanaan kegiatan ini;

2. Ketua LPPM dan Ketua Program Studi Kesehatan Masyarakat Universitas Mandala Waluya, yang telah memberikan izin pelaksanaan kegiatan;

3. Pimpinan Proyek Pembangunan Kantor Walikota Kendari yang telah memberikan izin dan menerima kami dalam bersosialisasi; dan

4. Adik-adik mahasiswa program Studi Kesehatan Masyarakat yang terlibat dalam kegiatan ini.

\section{DAFTAR PUSTAKA}

Budiman. (2011). Penelitian Kesehatan. PT Refika Aditama.

Ramli, S. (2010). Sistem Manajemen Keselamatan dan Kesehatan Kerja
OHSAS 18001. Dian Rakyat.

Santia, T. (2021). Kemenaker Catat Kecelakaan Kerja di 2020 Naik Menjadi $177.000 \quad$ Kasus. https://www.merdeka.com/uang/ kemenaker-catat-kecelakaan-kerjadi-2020-naik-menjadi 177000kasus.html?page $=2$

Sumardiyono. (2010). Pengaruh Penyuluhan Kesehatan dan Keselamatan Kerja (K3) terhadap peningkatan pengetahuan K3 pada pekerja peternak ayam di Jaten Karanganyar / Kesehatan Kerja UNS.

https://kesehatankerja.wordpress. com/2010/12/14/pengaruhpenyuluhan-kesehatan-dankeselamatan-kerja-k3-terhadappeningkatan-pengetahuan-k3pada-pekerja-peternak-ayam-dijaten-karanganyar/

Tarwaka. (2008). Keselamatan dan Kesehatan Kerja "Manajemen dan Implementasi K3 di Tempat Kerja. Harapan Press. 